\title{
IMPROVEMENT OF BIOLOGY TEACHING*
}

\author{
RICHARD L. WEAVER \\ Conservation Department, School of Natural Resources \\ University of Michigan, Ann Arbor, Mich.
}

Two ten-day conferences have been held in 1954 and 1955 on the general problem of "How to Improve Biology Teaching in High School and College." Both were sponsored by the National Association of Biology Teachers on grants from the National Science Foundation.

The first one called the Southeastern Conference on Biology Teaching was held August 28 to September 6,1954 at the University of Florida at Gainesville, Florida. Ninety-four participants attended from the ten southeastern states, with some staff members recruited from NABT officers outside the region.

The second conference called the North Central Conference on Biology Teaching was held August 19-31, 1955 at the University of Michigan Biological Station at Cheboygan, Michigan. Eighty-six participants attended from ten of the north central states, with some of the staff also recruited from outside the region.

In both conferences, the participants were selected to form state teams with several high school teachers, several college biologists, several teacher trainers and a public school administrator and/or a member of the state department of education.

Four objectives were selected for the two conferences. Objective number one dealt with the proper role of certain content areas in biology. At Florida the areas considered were morphology, taxonomy, physiology, evolution and paleontology, genetics, ecology and conservation. At Michigan the content objective centered on the contributions of biology to living and the following areas were selected: food supply of man, plants and man, conservation of natural resources, human inheritance, and health and disease.

The second objective was: To analyze and select some of the most important problems of biology teaching at various levels of instruction and in State Departments of Public Instruction.

The third objective was: To develop a set of recommendations for the solution of the selected problems.

The fourth objective was: to formulate plans by state teams for implementing the recommendations.

\footnotetext{
* Read before the Biology Section of the Central Association of Science and Mathematics Teachers, November 25,1955 , at Detroit.
} 


\section{Organization of the Conference}

Part I of the conferences was organized around discussions on the content areas.

Each of the scientists who served as consultants for each conference was asked to prepare a working paper in the area he represented, to include the following:

1. The essential subject matter necessary for the preparation of the high school teacher,

2. The most recent scientific developments of significance to that area, and

3. The experiences and methods by which such content might be transmitted to students.

The particpants were placed in five groups with as great a distribution geographically and professionally as possible.

The consultant and his recorder met with each of the small groups for two hours to discuss the content of the paper and for two more hours to discuss ways of teaching the material to teachers or to high school students.

Part II of the conferences was organized around problems of teaching biology in high school and college and problems related to certification and state department leadership.

These problems were selected by the participants, and considered in small groups. Specific recommendations on each problem were prepared by each of four groups at each of the conferences.

At general sessions the groups reported their recommendations and agreement was reached as to which recommendations were to be accepted as conference recommendations.

Part III of the two conferences was set aside for state teams to make their plans for implementation of the recommendations in their own states.

\section{CONFERENCE LEADERSHIP}

At the Florida Conference the staff consisted of Dr. Samuel Meyer of Florida State University and Dr. Richard L. Weaver of the University of Michigan as Co-Directors, Dr. Ned Bingham of the University of Florida; Dr. Hugh Stickler of Florida State University and Dr. George Jeffers of Longwood College in Virginia.

The science consultants were Dr. Herbert P. Riley, University of Kentucky; Dr. Loren C. Petry of Cornell University; Dr. C. S. Chadwick of Peabody College for Teachers; Dr. Fred R. Cagle of Tulane University; Dr. F. R. Hunter of Florida State University and Dr. Royal E. Shanks of the University of Tennessee. Numerous educational consultants from universities and state departments of education assisted in Part II of the conference. 
At the Michigan Conference the staff consisted of Dr. Richard L. Weaver, University of Michigan as Director, Dr. Richard Armacost of Purdue University, Paul Klinge of Howe High School, Indianapolis, Dr. John Breukelman of Kansas State Teachers College, and Dr. Alfred Stockard of the University of Michigan Biological Station.

The Michigan science consultants were Dean Emeritus Samuel T. Dana and Professor Robert Bowman of the University of Michigan, Professor Harry Fuller, University of Illinois, Professor Harold O. Goodman, Michigan State University and Professor John S. Karling of Purdue University.

Special educational consultants were Dr. Robert Koopman of the Michigan Department of Public Instruction and Dr. Dorothy McCuskey of Bowling Green State University in Ohio.

The Report of the Florida conference was published as the January 1955 issue of the American Biology Teacher. Some copies are still available from Paul Webster, Secretary-Treasurer of NABT, at Bryan City Schools, Bryan, Ohio.

The complete Report of the Michigan Conference has been published as the January 1956 issue of the same Journal and also can be ordered from Paul Webster.

A brief summary of the over-all recommendations of the two conferences follows:

\section{FLORIDA}

Many of the problems discussed by persons attending the Florida conference were related to the acute shortage of qualified high school biology teachers. The United States Office of Education has recently issued the statement that less than $60 \%$ of the high school biology teachers have the equivalent of a college major in that field. As high school enrollments increase, this shortage is becoming more acute. At the same time, an increasing number of high schools are requiring all students to have courses in biology and a decreasing number of college graduates are choosing high school biology teaching as a profession.

The Conference approached this problem from two standpoints: to improve the quality of training for the high school biology teacher and to make his job more attractive after he has gotten into it.

To improve training the Conference recommended that the prospective high school biology teachers have a college major in biology which will include one year of General Biology or courses in General Botany and General Zoology. At least one-third of this training should be in plant science. The Conference recognized the need for field studies in the teacher's advanced training. To provide a broad 
training that will make modern biology meaningful and, at the same time, qualify the teacher to instruct in related scientific fields, it was recommended that he have a year each of chemistry and physics, with laboratory work, a year of mathematics and some training in earth science. It was further recommended that he take the necessary education courses to fulfill his state's certification requirements. A course in the methods of teaching high school biology was considered essential. It was agreed that the high school biology teacher should have the same broad training in the humanities, social studies and communication skills as teachers in other areas. The Conference regarded these recommendations as the minimum training needed by the high school biology teacher to prepare him for his work.

The Conference recognized the need for helpful consultant services to be provided the high school teacher. It was felt that the needed advice was too often lost in other assignments. For that reason, the Conference recommended that the various states take the necessary steps to concentrate their consultant services in the hands of a single individual who would have no other major responsibilities.

In order to meet the demands for increased numbers of high school biology teachers, the Conference recommended that his position be made more attractive by the establishment of salary and pension schedules more nearly comparable to those of other professional groups in industry and government which require comparable training, by encouraging promising high school students to choose biology teaching as a profession and by issuing temporary certificates to persons who do not meet the minimum requirements provided they continue their professional training toward meeting such requirements.

The Conference recognized that the high school student is to be trained to take his part in community life and that his work in biology should make a definite contribution to that goal.

\section{MICHIGAN}

Some of the recommendations from the Michigan Conference are: (1) Colleges should continue and increase their efforts to help recruit, train, and assist high school teachers of biology; (2) College and professional groups should continue and increase their efforts to hold refresher-type conferences, institutes, and classes to help teachers in service to keep up with new developments in science; (3) College administrators should arrange for cooperative planning between science departments and the educational departments or schools to assure adequate training in science as well as in education; (4) Colleges should arrange to have beginning courses taught by those 
scientists who are richest in experience, most enthusiastic about their subject, most effective in exposition, and most interested in students; (5) Colleges should provide seminars for college teachers on educational philosophies, teaching methods, and the problems confronted by college teachers; (6) Colleges should develop curricula for high school teachers which will meet their specific needs; (7) College scientists should continue and increase their efforts to help high school teachers and students so as to stimulate the more gifted students into electing science as a career; (8) High Schools should plan their biology programs so as to better meet the individual needs of all students, and especially the gifted ones, and should make a greater and more effective use of better teaching methods, texts, and audio-visual materials through community study, group work, and use of outdoor laboratories, school camps, forests, and gardens. (9) High school teachers should keep themselves up to date through use of professional organizations, advanced study, and cooperative planning with other subject matter groups, and (10) State departments of education should use scientists and science teachers more generally in helping to establish certification requirements for teachers.

A more detailed summary of some of the recommendations aimed at improvement of high school biology teaching includes the following:

\section{Meeting Student Needs in High School:}

In order to insure adequate recruitment and education of future scientists, sound and stimulating science teaching is needed from elementary grades through high school. It sould include a biology course which meets the individual needs of all pupils. Capable students interested in science should have an opportunity to become acquainted with working scientists. Teachers should make it possible for all students to work at their maximum ability through a flexible program in which students help to determine and to achieve many of their own objectives and all of the valuable scientific resources of the school and community are utilized.

\section{Using Scientific Methods in Teaching:}

One of the primary objectives of the high school course in biology is to develop scientific attitudes in students. The teacher must be informed on the problem of the nature and meaning of science and the methods of science. A distinction needs to be made between the creation of science through research, and the application or use of science. Teachers must use the methods, approaches, and attitudes 
of scientists. They should use some of the classics of science and show how the scientists attacked their problems. Students should have the opportunity for experiences in using scientific methods in securing answers for themselves.

Interrelationships between Biology and Other Areas and Levels of the School Curriculum:

Some relief from an over-crowded and ever-expanding biology course can be achieved through better and more continuous science teaching in the elementary and junior high grades. Cooperative planning between teachers, administrators, and students can strengthen the science programs in the direction of better preparing all students for living and for further work in science. Students need opportunities to apply in other classes what they have learned in biology, and biology should help other teachers achieve some of their objectives too.

\section{Effect of Scientific Developments and Social Trends on Biology Courses:}

Biology cannot remain static. The use of modern drugs, the increasing need for conservation, and the judicious use of land and water to feed millions more people, the whole field of biophysics, requires an ever changing biology course. Teachers have, and need to use, the many opportunities for keeping up-to-date through their professional journals, refresher courses and institutes at colleges, and in-service study programs. More intensive science courses can be achieved too, if greater emphasis is placed on strengthening the mathematics courses in high school.

\section{Improving Methods of Instruction:}

Experience has demonstrated the necessity for the use of many methods and techniques in the teaching of biology. The teacher should be familiar with many methods in order to select wisely the proper methods to fit best the situation. Better use of texts, references, and audio-visual materials, more adequate appraisal and wider use of community resources, particularly out-door laboratories, study areas, school camping, school forests, gardens and the like.

A multi-text system or classroom library is generally preferable to the use of a single text. This discourages the use of the text as the prescribed course of study; encourages comparison, may aid in critical thinking and may encourage a greater variety in the types of teaching activities. School budgets should include provision for purchase of desirable materials and apparatus necessary for good teaching procedure. 


\section{Administrators Can Help to Improve Biology Teaching:}

By obtaining the best cooperative thinking of all groups, including the science teachers, some laymen and scientists, many of the most pressing problems related to class size, adequate laboratory and library facilities, adequate financial support, and teaching load, much progress can and needs to be made. Alert and progressive administrators are doing this continuously now, and should help each other in a united effort of school improvement.

Better planning of science rooms with more flexibility should result in a richer program with more contact with live and prepared materials, more experiments, more use of audio-visual aids, and references. Science teachers should be provided with a preparation period, and their load should be determined by the number of contact hours with students, plus preparation needs.

For the detailed recommendations concerning biology teaching in college, and ways state departments and other administrative units can help to improve biology teaching, it is suggested that you secure a copy of the January 1956 issue of The American Biology Teacher for a complete report.

\section{PROFESSOR SATHER, CONSERVATION EDITOR}

Dr. J. Henry Sather received his B.Sc. degree from the University of Nebraska in 1943, M.A. degree from the University of Missouri in 1948, and Ph.D. from the University of Nebraska in 1953.

During the years 1948 to 1955 , Dr. Sather was associated with the State of Nebraska Game, Forestation \& Parks Commission. From 1948 to 1954, he was in charge of the fur investigational phases of the Nebraska Pittman-Robertson program. In this capacity, he conducted an intensive study of the life history and ecology of the Great Plains muskrat. In 1954, Dr. Sather was placed in charge of Nebraska's Pittman-Robertson Investigational Projects. In this capacity he planned and administered upland game, waterfowl, and furbearer research studies.

In September, 1955, Dr. Sather accepted a position on the staff of the Department of Biological Sciences of Western Illinois State College at Macomb, Illinois. His decision to enter the teaching profession can largely be attributed to his conviction that the greatest need in the conservation field today is a sound conservation education program. 